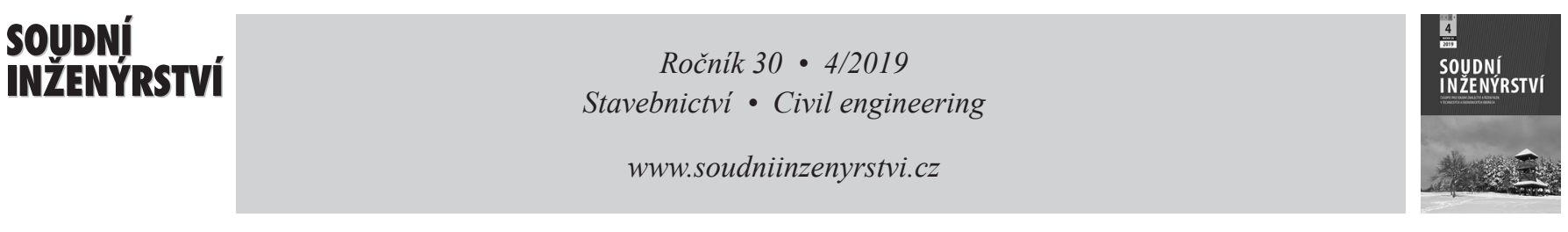

\title{
Analýza porúch rekonštrukcie hlineného domu
}

\author{
Ján Hollý*, Martina Jurigová \\ Slovenská technická univerzita Bratislava, Stavebná fakulta
}

Analysys of Defects in the Reconstructed Clay House

\begin{abstract}
Abstrakt
Napriek tomu, že kvalita stavebných materiálov a know-how v oblasti projektovania sú na vysokej úrovni, poruchy stavieb sú stále bežné. V tomto prípade pravdepodobnost' vzniku poruchy rekonštruovanej budovy čiastočne umocnil fakt, že steny sú z hlinených (nepálených) tehál. Avšak tento fakt nebol jedinou príčinou nedostatkov. Tento článok popisuje niektoré vybrané defekty. V závere sú uvedené zistenia a odporúčania na opravu. Tento článok bol prezentovaný na konferencii JuFoS 2019.
\end{abstract}

Klíčová slova: rekonštrukcia tehlového domu z nepálenej hliny, poruchy.

\begin{abstract}
Despite the fact that the quality of the building materials and designing know-how reaches its peak values, the displays of construction imperfections are still widely common. In this case, however, the process of building reconstruction was partly hindered by the fact that the walls were made of clay bricks. Unfortunately, this was not the only cause of defects. This paper presents the evaluation of some of the chosen defects. Final findings and recommendations for maintenance are stated in conclusion. This article was presented at the JuFoS 2019 conference.
\end{abstract}

Keywords: clay brick house reconstruciton, defects.

\section{POPIS STAVU V ČASE OBHLIADKY}

Predmetná stavba je nepodpivničená dvojpodlažná budova. Dom je navrhnutý na bývanie, spoločenská čast' je na 1.NP, na poschodí je čast' nočná. Prvé podlažie je čiastočne konštrukčne prerobené, druhé nadzemné podlažie je kompletne nadstavané.

Pôvodný dom z nepálených tehál na 1.NP je rekonštruovaný keramickými tvárnicami, s čiastočne zachovanými hlinenými nosnými stenami. Ako nová nosná konštrukcia gánku na východnej strane sú realizované stípy z debniacich tvárnic vyplnené betónom, usadené na prepojených železobetónových pätkách (obr. 2). Na týchto stípoch a vôkol celej budovy je zhotovený železobetónový veniec. Na tomto je d'alej vymurovaná obvodová stena 2.NP z keramických tehál, stužená železobetónom, na ktorom je položená pomúrnica nesúca hambálkový strešný krov. Vnútorné priečky v na 2.NP sú z pórobetónových tvárnic.

Zatial' neboli vykonané žiadne deštruktívne skúšobné metódy (sondy v konštrukciách). Stav konštrukcií je známy len podl'a povrchovej/ finálnej úpravy. Na prízemí je vyliata betónová podlaha. Nosná konštrukcia stropu 1.NP je zrealizovaná z nosných trámov, prekrytých plnoplošným záklopom. Podlaha 2.NP je betónová. Strecha má z vnútornej strany osadenú paronepriepustnú fóliu, krytina strechy je z rákosu. Boli vymenené všetky otvorové konštrukcie.

\section{ANALÝZA STAVU}

Nepálená tehla (prakticky stlačená hlina) je materiál, ktorý aj napriek tomu že dokáže regulovat' vlhkost' vnútorného prostredia, vel'mi citlivo reaguje na pôsobenie vody alebo vysokej vlhkosti. Okrem toho má tento už žial' málo používaný stavebný materiál značne odlišné mechanické vlastnosti než stavebné hmoty súčasnosti. Navyše jej vlastnosti závisia aj od rôznych prímesí. Preto je potrebné pristupovat' $\mathrm{k}$ rekonštrukcii takýchto stavieb vel'mi obozretne a s rešpektom, čo účastníci predmetnej stavby v niektorých prípadoch opomenuli. Navyše je proces rekonštrukcie momentálne pozastavený a mnoho miest tak vol'ne degraduje.

\subsection{Nedostatky súvisiace s charakterom hlineného materiálu} Historické stavby z nepálených tehál sú zväčša jednopodlažné stavby, čo platilo aj pre predmetný dom. V prípade, že sa investor vo všeobecnosti rozhodne pre nadstavbu, je potrebné dodatočne upravit' i základy. Za týmto účelom musí odborne spôsobilá osoba vykonat' obhliadku, posúdit' stav jestvujúcich základov a za obnaženej základovej škáry určit' kvalitu podložia. Na základe zistených okolností by mal statik navrhnút' spôsob zosilnenia základu. V tomto prípade bolo navrhnuté podchytenie hlinenej steny zo severnej a západnej strany stavby podl’a obr. 3. Statik ale 


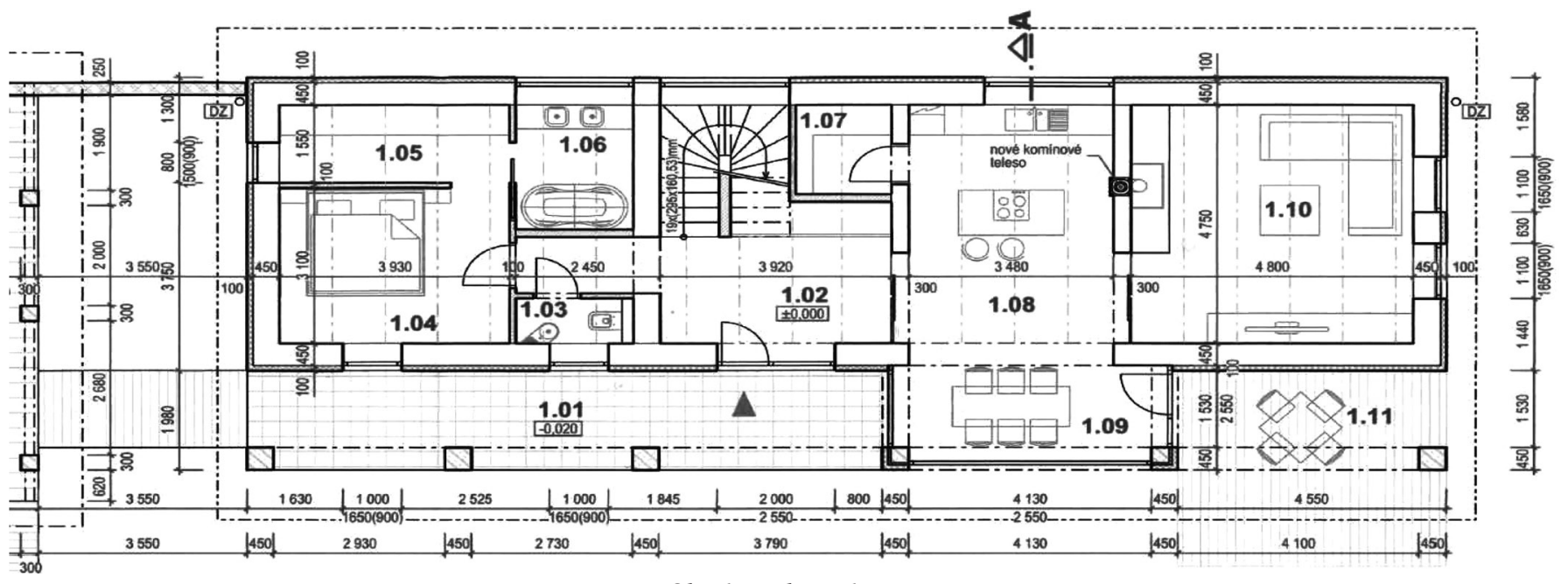

Obr. 1 Pôdorys 1.NP.

Fig. 1 Ground floor.

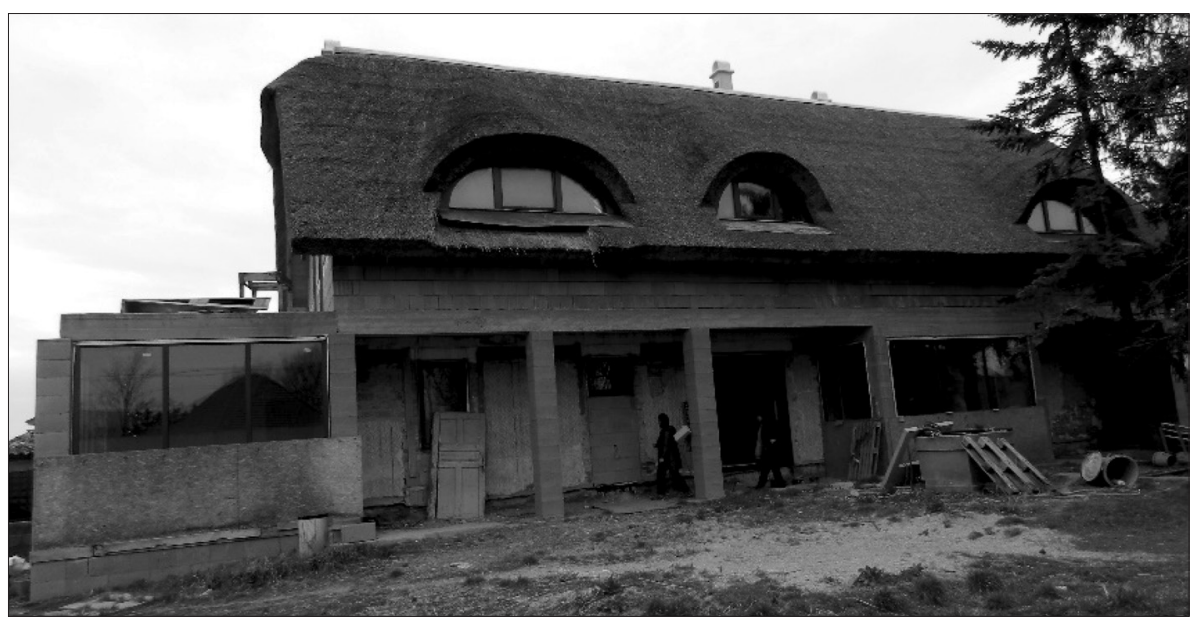

Obr. 2 Pohl'ad na východnú čast'stavby. Fig. 2 Eastern view.

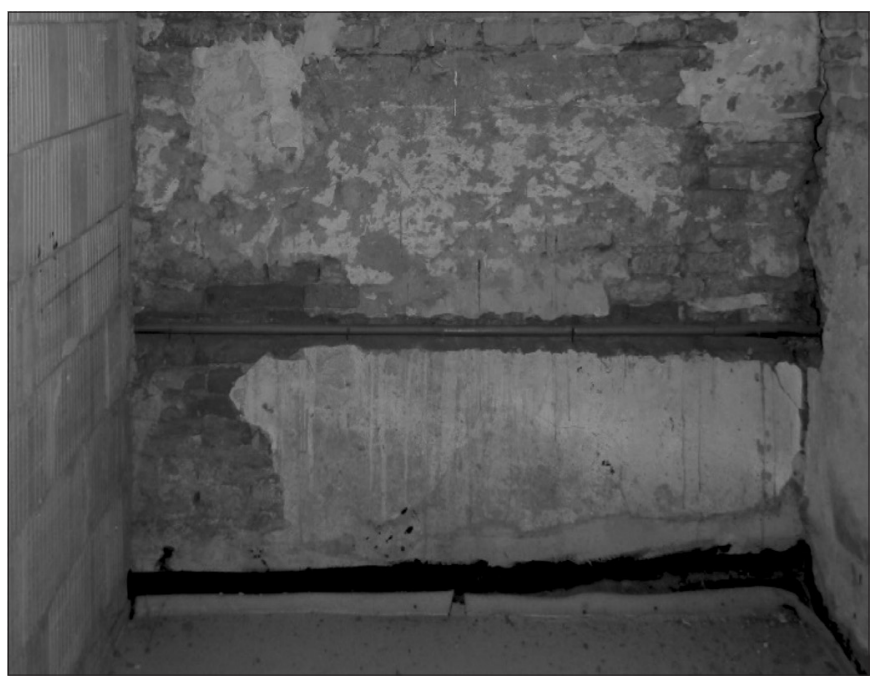

Obr. 4 Vedenie rúry v škáre muriva z nepálenej tehly; trhlina v kúte. Fig. 4 Piping in the brickwork; crack in the corner.

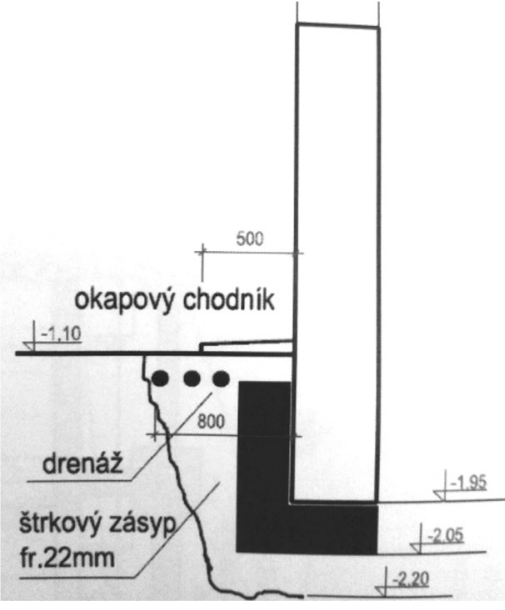

Obr. 3 Návrh podchytenia pôvodných základov.

Fig. 3 The design for additional foundations under the original ones.

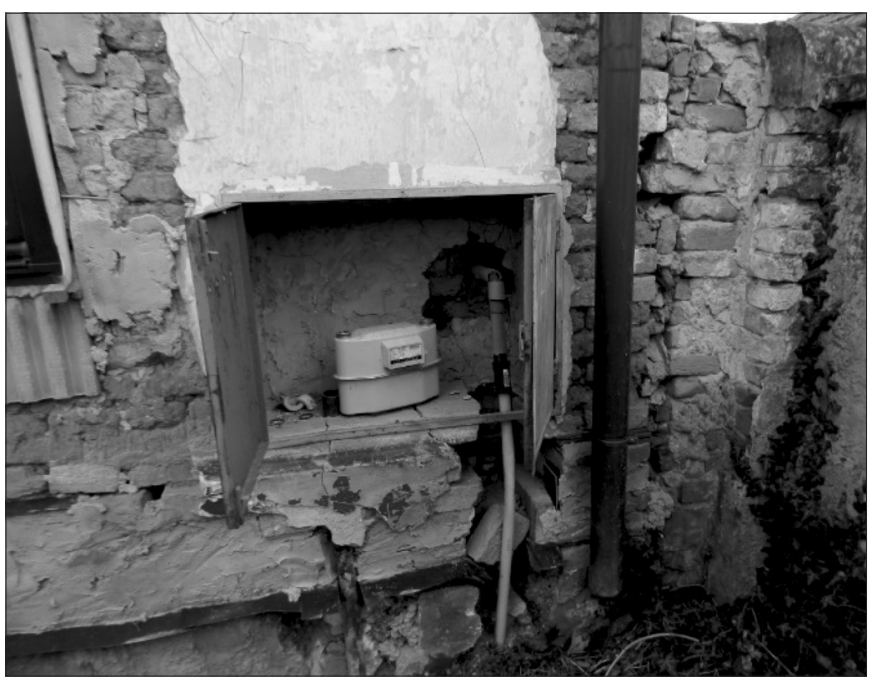

Obr. 5 Výklenok v škáre muriva z nepálenej tehly; odvodnenie strechy priamo ku základu; absencia hydroizolácie spodnej stavby. Fig. 5 A recess in the brickwork; roof drainage directly to the foundation; absence of foundation waterproofing. 


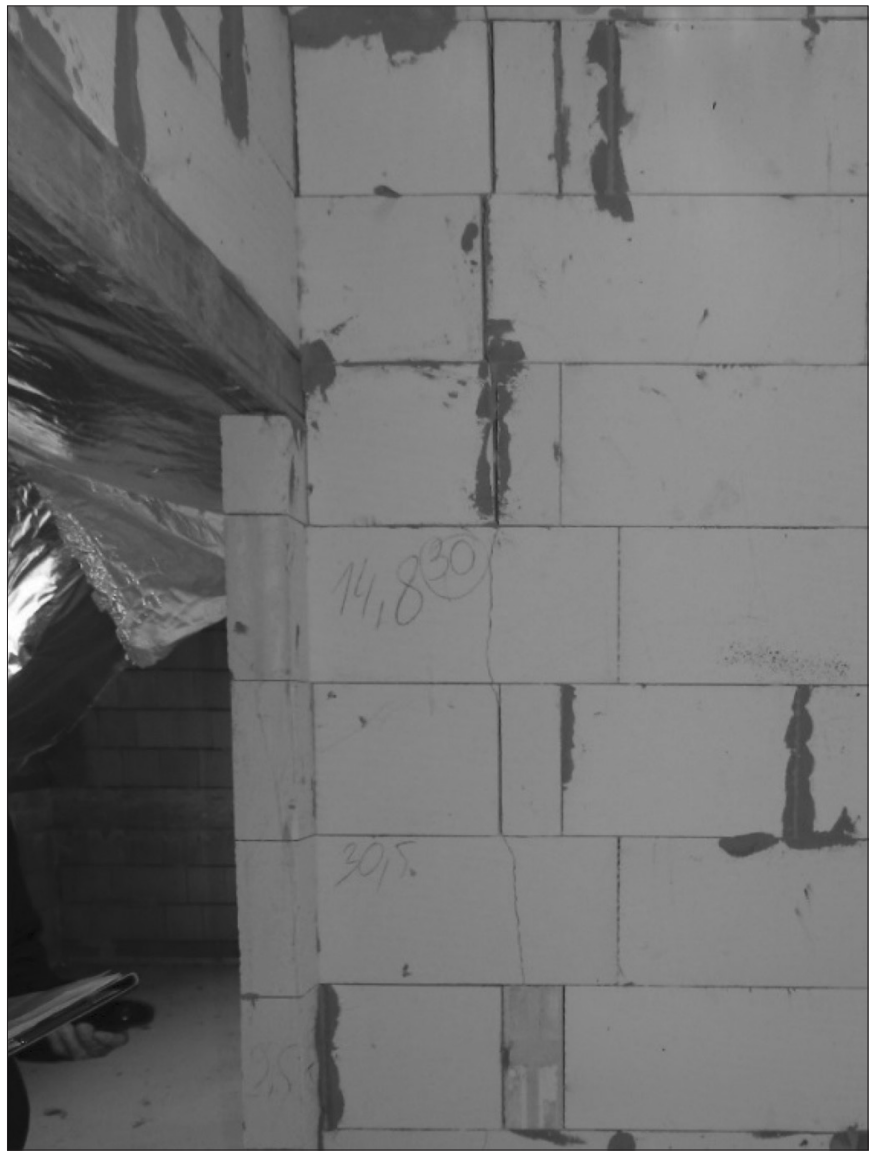

Obr. 6 Zvislá trhlina v stene 2.NP.

Fig. 6 Vertical crack in the 1st floor wall.

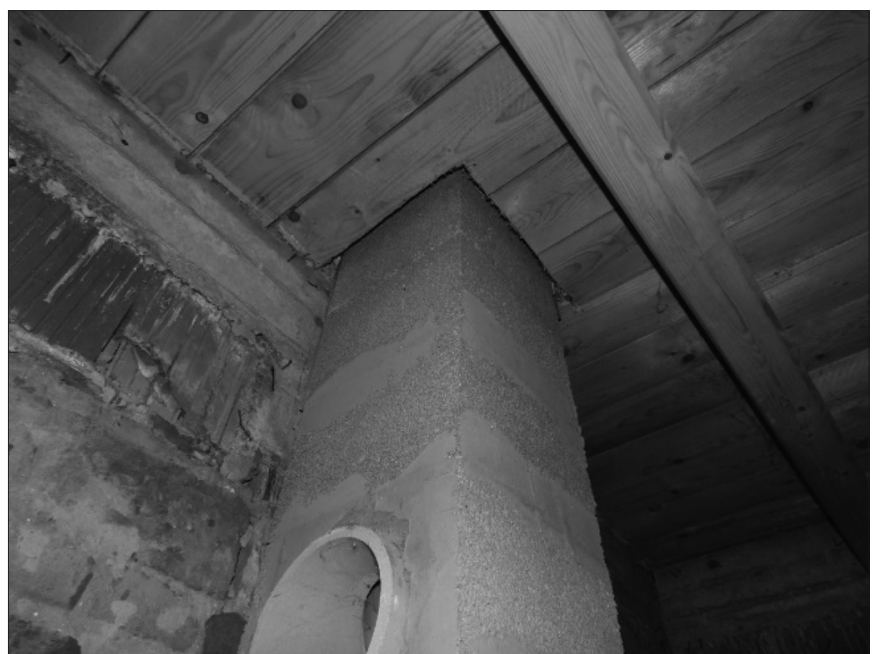

Obr. 8 Nedostatočne vel'ké odstupy horl'avých konštrukcií od telesa komina.

Fig. 8 Insufficient distances of flammable structures from the chimney.

v správe popisuje, že jestvujúci základ bol z prostého betónu, čo je nepravdepodobné vzhl'adom k typu takýchto stavieb [1] (základ bol bud' kamenný, zmiešaný s hlinou, alebo nebol žiaden). Bude potrebné odhalit' túto čast' stavby a posúdit' jestvujúci stav. Je totižto vysoko pravdepodobné, že bud' nesprávnym návrhom, zhotovením, alebo kombináciou týchto predpokladov stavba sadla a tým pádom

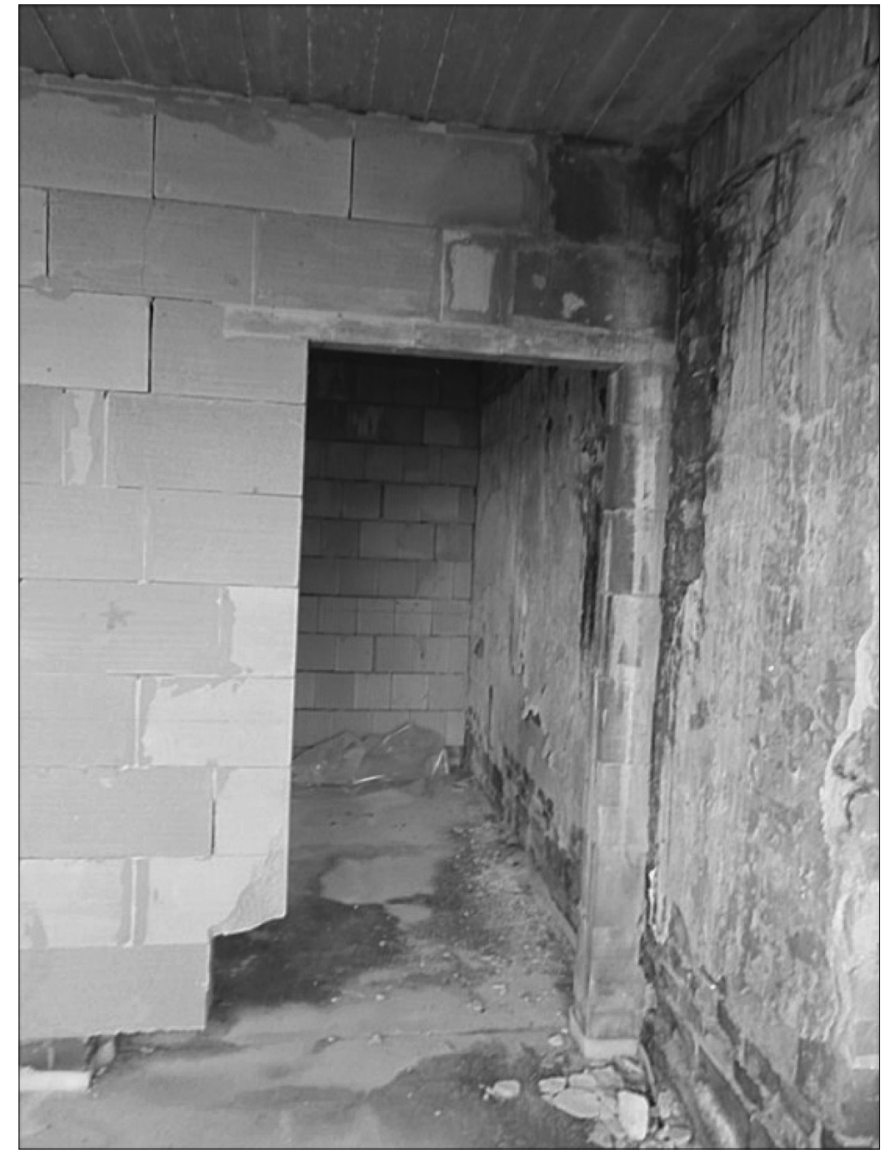

Obr. 7 Prejav zatekania z otvorenej terasy.

Fig. 7 Sign of leaking from the terrace above.

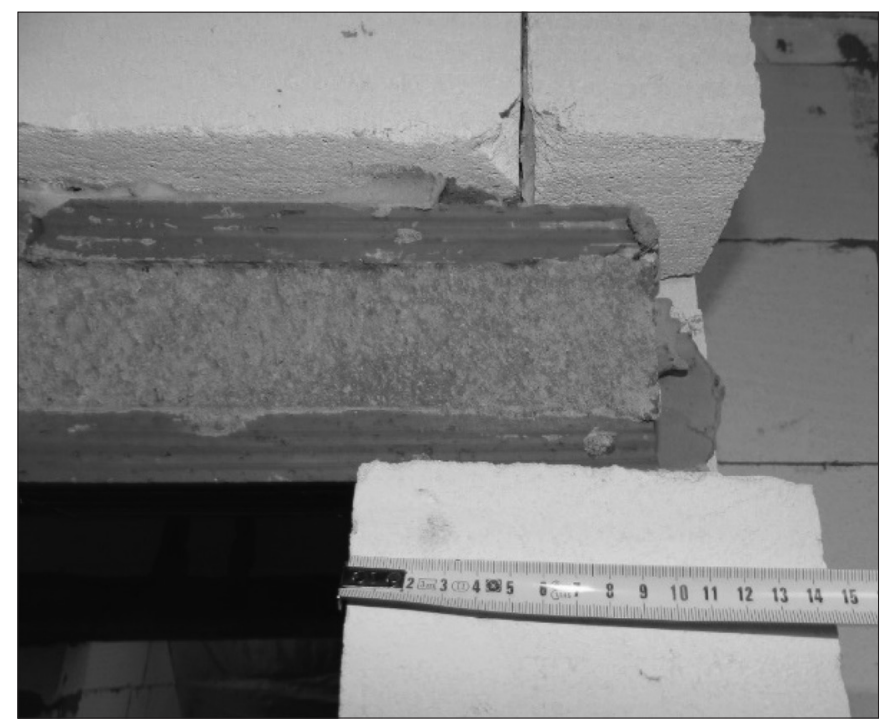

Obr. 9 Preklad s nedostatočnou dĺžkou uloženia a zlou orientáciou. Fig. 9 Insufficient bearing length and poor orientation.

vznikajú trhliny v nadstavbe objektu (obr. 6). Tento defekt navyše umocňuje oslabenie hlinenej steny škárami a výklenkami (obr. 4, obr. 5). Absentuje akékol'vek posúdenie jestvujúceho materiálu, čo by malo byt' pri nadstavbe $\mathrm{v}$ takejto citlivej konštrukcie pravidlom. Do tretice môže sadnutie podporovat' vyhotovenie kontaktu medzi hydroizoláciou hlinenej steny (novým podrezaním) 


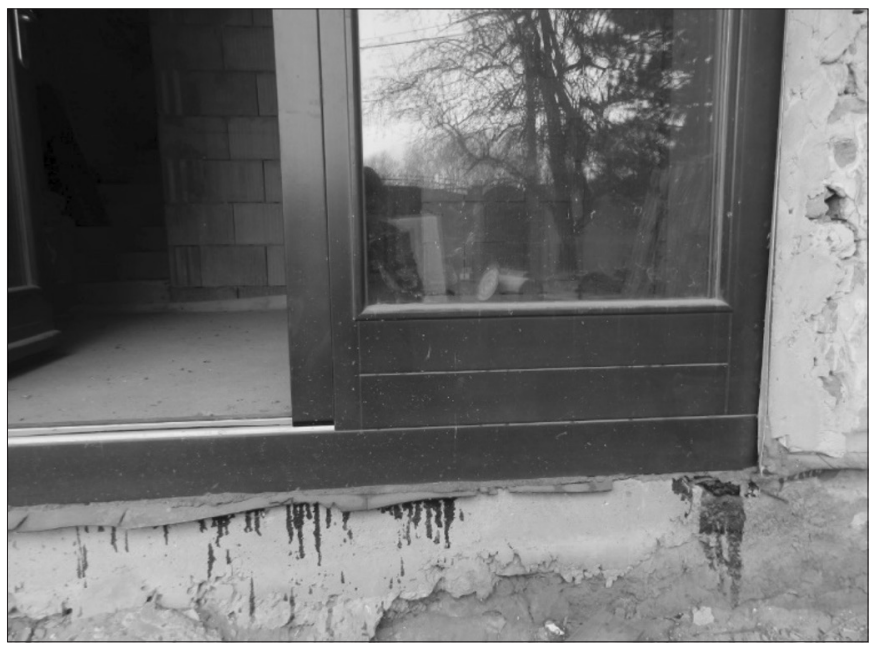

Obr. 10 Absencia hydroizolačnej úpravy.

Fig. 10 Absence of waterproofing.

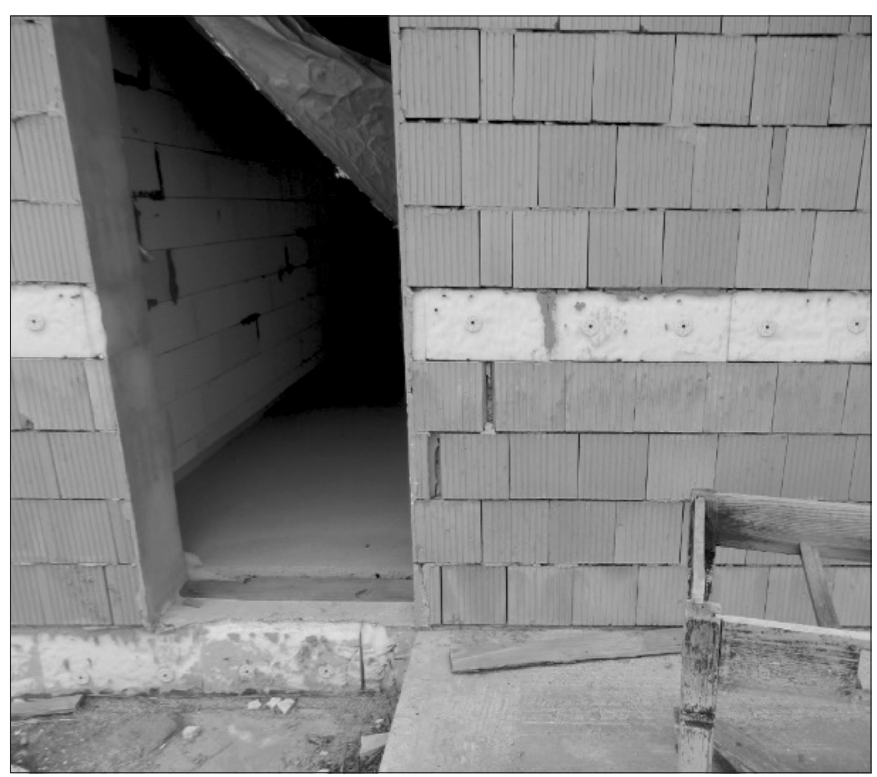

Obr. 12 Prerušenie obvodového venca.

Fig. 12 Concrete stiffening break

a hydroizoláciou nových vrstiev podlahy. Ako bolo v úvode spomínané, hlinené murivo je náchylné na zvýšenú vlhkost', a teda zmenou pomerov v týchto miestach mohla byt' tehla oslabená.

\subsection{Nedostatky nesúvisiace s charakterom hlineného materiálu}

Na stavbe bolo tiež vyhodnotených niekol'ko d'alších chýb, či už $\mathrm{v}$ réžii projektu alebo zhotovitel'a objektu:

- zhotovitel' nedodržal podklady projektovej dokumentácie:

- miestnost' pod južnou terasou na 2.NP nie je v projekte, po zastavení prác nebola vyhotovená hydroizolácia, do tejto miestnosti zateká, znehodnocuje sa murivo (obr. 7),

- vytvorené betónové schodisko namiesto navrhnutého dreveného (obr. 13),

- jeden $\mathrm{z}$ troch komínov nie je $\mathrm{v}$ dokumentácii (má základ?),

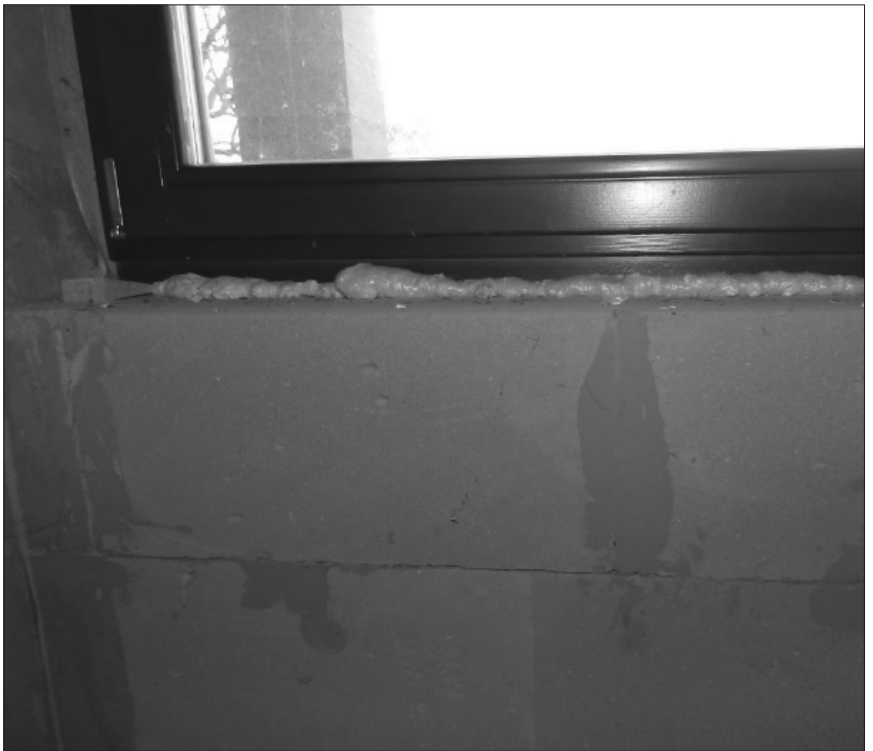

Obr. 11 Absencia paronepriepustnej úpravy.

Fig. 11 Absence of vapor-nonpermeable treatment.

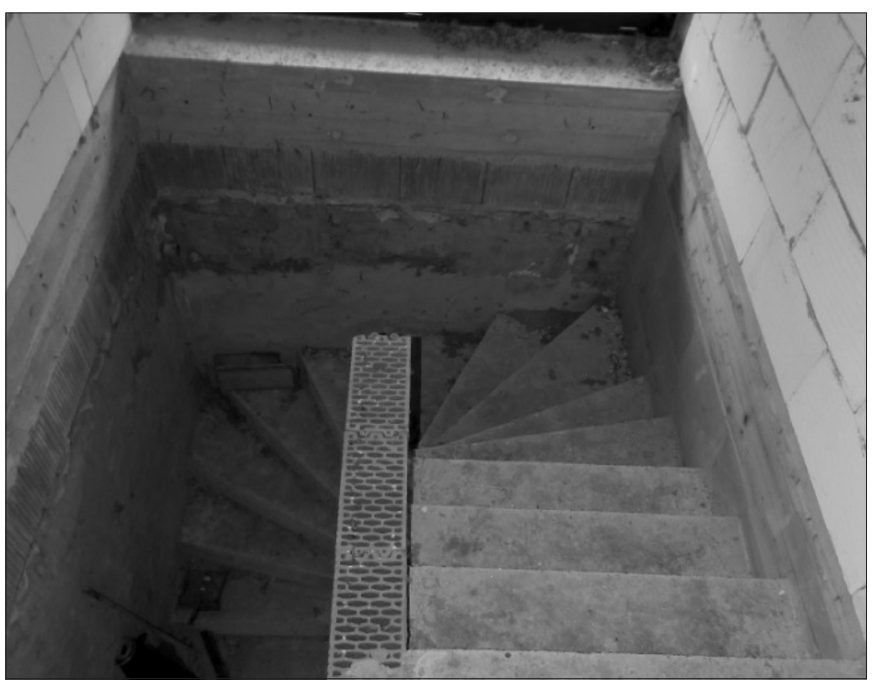

Obr. 13 Betónové schodisko na tehle z nepálenej hliny; v projekte je schodisko drevené.

Fig. 13 Concrete staircase on clay bricks; the project states a wooden staircase.

- pórobetónové tvárnice na 2.NP namiesto l'ahkej sádrokartónovej konštrukcie (obr. 6),

- kanalizácia nevyvedená nad strechu (obr. 2),

- nedodržaný odstup komína od horl’avého materiálu (obr. 8),

- preklady nad dverami v interiéri s nedostatočnou dížkou uloženia a zlou orientáciou (na „kánt“) (obr. 9),

- absencia a nesprávne vyhotovenie pások a hydroizolácie v pripojovacej stavebnej škáre okien (obr. 10, obr. 11),

- zle navrhnutá (chýbajúca) vrstva PE fólie v podlahe 2.NP; na záklop je podl'a dokumentácie navrhnutá železobetónová škrupina a až následne PE fólia; skladba bola takto aj zhotovená; drevo môže začat' degradovat' pôsobením plesne a hniloby (obr. 13),

- prerušenie obvodového venca (obr. 12),

- chýbajúce oddelenie drevených prvkov od betónových. 


\section{ZÁVER}

Na základe prvotnej obhliadky stavby bolo vyhodnotených niekol'ko nedostatkov ktoré majú vplyv na užívanie a bezpečnost'. Je potrebné vyhotovit' sondy za účelom zistenia stavu základovej konštrukcie, a tiež skladby jednotlivých podláh. Jediným východiskom z tejto situácie je následne posúdenie stavu znalcom z odboru statika a navrhnutie rekonštrukčných úprav. Stavba však vykazuje tol'ko porúch, že je otázne, či oprava $v$ takomto štádiu nebude finančne náročnejším riešením ako takúto stavbu úplne rozobrat'.

\section{LITERATÚRA}

[1] ŽABIČKOVÁ, I. Hliněné stavby. 1. vydání, Vydavatelství ERA 2002. 174 s. ISBN 80-86517-18-7.

[2] STN 733134 Stavebné práce, Styk okennich konštrukcii a obvodového plášta budovy, Požiadavky, zhotovovanie a skúšanie. Úrad pre normalizáciu, metrológiu a skúšobíctvo SR, 2014. $32 \mathrm{~s}$

[3] STN ISO 730038 Zásady navrhovania konštrukcií, Hodnotenie existujúcich konštrukcií. Slovenský ústav technickej normalizácie, 2012. $80 \mathrm{~s}$.

[4] HOLLÝ, J., JURIGOVÁ, M. Analýza porúch rekonštrukcie hlineného domu. In: Sborník přispěvků konference Junior Forensic Science Brno 2019, Vysoké učení technické v Brně, Ústav soudního inženýrství, 2019, s. 131-134. ISBN 978-80-214-5730-0.

\section{Správná citace:}

HOLLÝ, J., JURIGOVÁ, M. Analýza porúch rekonštrukcie hlineného domu. Soudní inženýrství, 2019, 30(4), 18-22. DOI: http:// dx.doi.org./10.13164/SI.2019.4.18. ISSN 1211-443X.

\section{Expert Forensic Science ExFoS}

\section{9. ročník mezinárodní vědecké konference Expert Forensic Science (ExFoS) $29^{\text {th }}$ International Scientific Conference of Expert Forensic Science (ExFoS)}

Ve dnech 23. - 24. ledna 2020 se uskuteční další ročník mezinárodní konference, která se stane součástí oslav 50. výročí založení Ústavu soudního inženýrství VUT v Brně. Konference je pořádána ve spolupráci s Asociací znalců a odhadců České republiky a Evropskou společností pro výzkum a analýzu nehod - Národní skupinou ČR.

Tematické oblasti:

- Společná část (přednášky týkající se výkonu znalecké činnosti)

- Analýza silničních nehod oceňování motorových vozidel, strojů a zařízení (doprava, strojírenství, ekonomika)

- Stavebnictví a oceňování nemovitostí (vady a poruchy, oceňování nemovitostí)

- Inženýrství rizik (bezpečnost a rizika technických a ekonomických systémů)

Více informací naleznete na www.exfos.cz
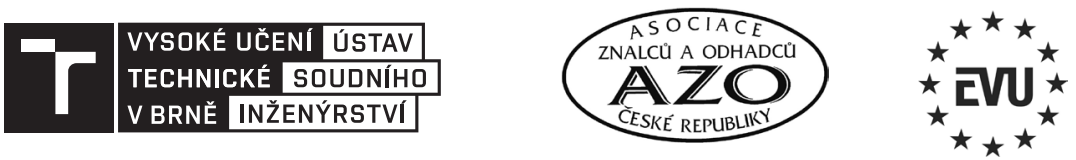